\title{
The Impact of eWOM in Social Media on Consumer Purchase Decisions: A Comparative Study between Romanian and Bosnian Consumers
}

\author{
Mersid POTURAK ${ }^{1}$ \\ Merve TURKYILMAZ2
}

\begin{abstract}
Marketers define their social media platform as an essential piece to reach their consumers. The flock of web users turning to social media to receive and convey their thoughts, opinions, and suggestions has made social media an integral part of digital marketing. Using traditional media to advertise had restrictions in placement and outcome while, nowadays, social media has liberated this obstacle. It has created a platform which allows information to spread freely and at a fast pace. Using electronic word-of-mouth in social media permits a constant connection to a vast audience. The purpose of this study is to explore the effect of electronic word-of-mouth within the context of social media on consumer purchase decisions. More precisely, how the familiarity of the Electronic Word of Mouth (eWOM) source, the way of communication, writer's expertise and the popularity of a product affects the consumer's purchase decision. The data has been gathered using quantitative research method. The sample consists of students studying in Sarajevo and Timisoara. Having sample from two different countries would be good base for comparative analysis. The survey for data analysis was emailed to students' email addresses. The results of the analysis will provide a comparison between the universities and the level of impact eWOM in social media has on their purchase decisions.
\end{abstract}

KEYWORDS electronic word-of-mouth, social media, digital marketing, purchase decision.

JEL CLASSIFICATION $M 3, M 31, M 37$

\section{INTRODUCTION}

The constant escalation of the internet usage drove companies to mend their marketing strategies to include the digital interactivity of their customer base. Digital marketing is defined as; "a subcategory of marketing which uses digital technology to place and sell products." It is the marketers' use of technologies such as; emails, social media and word-ofmouth to engage with their target group and generate sales. What sets digital marketing apart from traditional marketing is the ability to comprehend the efficiency of the marketing campaigns while they are still being served to the online viewers.

The choice procedure and psychosocial movement are involved in the phases of assessing, buying, devouring or requesting any good or service. As the Internet advanced, along with globalization, the buyers started to confront the issue of "perplexity by over-decision". The various brands accessible for a similar item perplexes the customer to make up his/her mind on which brand to choose. Thus, there is a solid requirement for a medium to slice through the advertising "mess" and help shoppers pick an item that will fit their needs. Electronic word-

\footnotetext{
${ }^{1}$ International Burch University, Sarajevo, Bosnia and Herzegovina, mersid.poturak@ibu.edu.ba

${ }^{2}$ International Burch University, Sarajevo, Bosnia and Herzegovina, turkylmz@ outlook.com
} 
of-mouth plays the role of this medium. Customers that decide to utilize this method for correspondence may have their buy goal adjusted, particularly by individuals who has had a shopping background with that good or service (Nawaz et al., 2014).

The way individuals see data sources influence their process of acknowledging the information being provided ( $\mathrm{Hu}, 2015)$. By the enhancements in web based shopping the significance of electronic word-of-mouth has extremely increased. When shoppers get recommendations from their closest or colleagues on social media they are able to instantly go to the websites which provide the product or service. If the person thinks about the suggestions given by someone he or she knows, the visit to the website can finish with purchase. This is one of the crucial elements which make eWOM better than traditional WOM (Evans \& Erkan, 2014).

Consumers are now in the position where they can immediately express their thoughts, give input, acknowledge or question the activity of a brand (Chiosa, 2014). These actions are possible because of the digital world we live in. By participating in web-based social networking, brands can create showcasing techniques that improve customer dedication and carry on the positive picture of the brand.

This study aims to examine the effect of electronic word-of-mouth within the context of social media. It focuses on whether the familiarity of the eWOM source drives the potential customer towards the purchase decision. The two-way communication on social media sites has allowed companies to expand their capacity to connect with the customers (Dellarocas, 2003; Lehmann, 2015). An analysis on whether this bidirectional communication positively effects the purchase decision will also be made. Finally, the effect of writer's expertise and the popularity of a product as motives to purchase will be explored.

\section{LITERATURE REVIEW}

\subsection{Differences between Electronic Word-of-Mouth (eWOM) and Traditional Word-of-Mouth (WOM) Marketing}

The sole difference between Electronic word-of-mouth (eWOM) and traditional word-ofmouth (WOM) is identified as the platform of communication being the Internet (Sørensen, 2010). Certain complementary factors support the differentiation. Electronic word-of-mouth has a vast amount of capacity to connect with the customers in a two-way communication when compared to traditional word-of-mouth (Dellarocas, 2003; Lehmann, 2015). Despite the fact that eWOM might have an additional impact over traditional WOM because of its viral way and due to the ability to connect any time the user searches to gain knowledge on a certain topic, the communication is notably more public than traditional WOM (O'Reilly \& Marx, 2011). While traditional WOM can only be experienced among acquainted individuals, electronic word-of-mouth encompasses data with a possibility of specified and unspecified origins (Flanagin \& Metzger, 2007).

\subsection{WOM vs. Viral Marketing}

According to the studies conducted by Vilpponen et al. (2006) there is an ambiguity in understanding the difference between viral marketing and word-of-mouth. Both terms are considered to be equivalent to each other. A clear distinction between viral marketing and word-of-mouth has to be made because the two can be mistakenly perceived as the same (Sørensen, 2010). Quite the opposite, viral marketing is a type of word-of-mouth used when the opinion leader is considered to have a positive influence (Lin et al. 2013). 
Beckmann \& Bell (2001) have stated that "Viral marketing is in its essence a communication strategy that uses ideas, slogans, catch phrases and icons or a combination hereof to transmit a message concerning a product as fast and as widespread as possible within a given target group. It is often part of a branding strategy and it usually seeks to address opinion leaders and often also early adopters".

Furthermore, electronic word-of-mouth is a basis used by potential customers to gain information about the experience from the already using customers. Even though they intersect at some points the differences are noteworthy. The main distinction is that strong word of mouth is principally dependent on the customers conveying their thoughts and opinions of the products which they have used; while viral marketing is designed to spread the knowledge of a product.

Based on the findings of Goodrich \& De Mooij (2014) the information obtained from known sources such as friends and families are seen as a part of the traditional media. Inclinations for data provided by humans are more critical in societies of short-term adjustments and low instability. On the other hand, certainty based data sources, for example, search engines are essential in societies where the adjustments take longer and high uncertainty is visible.

Facebook users which fall into the university age group are more willing to express their feeling on social media and advertising when compared to the non-group individuals (Chu, 2011). Still, the groups on Facebook do not apply an impact on the users' will to use viral advertising. Even though Facebook is used as a bridge by consumers to pass on their experiences with a product it is not effective as one might assume. Facebook users are shy to spread product related information. They believe that Facebook is primarily for having good connections with friends rather than an advertising tool. Even if these types of messages are sent by friends, the receiver might not feel comfortable with the message and be unwilling to spread the received text. Revealing their personal information in exchange to spreading viral messages is a criterion for Facebook users who are not willing to join Facebook groups. Selfstatus seeking is a noteworthy predictive factor of viral advertising behavior. The work of Sharif, Ahmad \& Ahmad (2016) had a focus on understanding whether or not the source credibility has an effect on the consumers' purchase intentions. The study conducted in two different cities proved that a statistically significant impact is visible on the consumers.

Website quality and purchasers' inclinations to utilize Facebook for web based shopping straightforwardly and emphatically influence shoppers' trust. On the hand, the recommendations coming from someone who the reader knows influences his/her attitude rather than the trust. The recommendations among female consumers are more effective when compared to male consumers (Nadeem, Andreini, Salo, \& Laukkanen, 2015). Even though users of a certain product or service are unwilling to post their experience, they are likely to be affected by the comments they read on social media sites. Based on the findings of Yogesh \& Yesha (2014), these sites are seen as platforms which are effective and valid. Based on the previous studies, the following hypothesis has been developed:

H1: The familiarity of the eWOM source positively affects the purchase decision.

\subsection{Motives to Use eWOM}

It is vital to comprehend the thought processes directing the online influencers to use electronic word-of-mouth. Understanding the motives is fundamental for those seeking to urge the influential individuals to spread messages. Knowing the thought processes in 
conveying online word-of-mouth can help organizations to create messages that will improve the viral movement and focus on the targeted customers.

When it comes posting comments online, consumers have three main reasons to spread the word (Cheung \& Lee, 2012). Firstly, customers like to tell their positive experience with the particular product and help others by easing their decision making between the various brands. Second, consumers want to alter the reputation of the brand. They have the desire to change the thoughts of other customers, whether it may be to improve the reputation or vice versa. Last, consumers have a sense of belonging to the products they use. In other words, they write their experiences online in order to show their commitment.

Based on the findings of Vilpponen et al. (2006) the network structure in the online environment is mostly affected by the mass media sources, the founder of the campaign and the communication platform. The likelihood of a consumer to adapt to the product differs between traditional and electronic communications. The network between the traditional platforms is stronger. Their research concludes that, as the strength between the relations of the parties grows the customers tend to adapt much quicker.

Consumers who are interested in social media posts about product experiences equally read and post themselves (Kietzmann \& Canhoto, 2013). They have the need to write on social media when their satisfaction level exceeds expectations. The positive and negative experiences are written under different social media sites based on the research of Kietzmann \& Canhoto (2013). The ones who would like to express their positively disconfirmed expectations choose to post on Facebook. On the other hand, consumers are more likely to post on twitter when it comes to negative feedback. Consumers have a variety of reasons to post or not post comments on social media sites. Some find it necessary when the ad of the product has humor within it, while some are afraid to express their complaints due to potential legal consequences. In addition, consumers expect the companies to be aware of their comments and take actions accordingly. They think that these sites serve as channels which they can easily use to reach the authorities of the brand or product in their mind.

The work of Hennig-Thurau et al. (2004) demonstrates the factors affecting the number of visits and the frequency of these visits on online platforms. Their findings indicate that the dominant reason for site visits is the social benefit. Furthermore, the number of comments is positively correlated with the social benefit motive. Their findings show that concern for other customers, extraversion/positive self-enhancement, social benefits, economic incentives, and to a lesser extent, advice seeking all have an impact on the number of visits and the frequency of these visits on online platforms.

The probability to advise a product based on an online review depends on where the reader has found the comment (Lee \& Youn, 2009). The popularity of tweets, especially for the ones related to the news, is tied with the source of the article rather than how well known the company itself is (Bandari, Asur, \& Huberman, 2012). Readers are more inclined to suggest the product when they have read it on and independent review website or the brand's own website. Additionally, the users urge to tell their friends about the product increases when they are satisfied and have had a pleasant experience. Nonetheless, consumers don't pay attention to which online platform they have commented on when it comes to writing reviews which focus on how dissatisfied they are with the product. Their only concern is reflecting their disappointment. On the other hand, the research of Burtch \& Hong (2014) points out that a significant difference exists between the reviews written on mobile and other devices. 
Consumers write their reviews right after consumption with a lot of emotion in short sentences. Moreover, the reviews are clear cut. This creates a base for the mobile reviews to be more useful to the readers of the comment.

Based on the findings of (Cheung et al., 2012), a negative correlation exists between the consumer expertise and consumer involvement. The consumer expertise has a negative impact, while the consumer involvement has a positive impact on the potential buyers of the product in question. The reference person plays a crucial role within the decision making process. Potential customers shape their brand choices based on the previous selections of their reference person. In addition, the quantity of the post made online has a significant effect on the number of purchases. This shows there is positive correlation between quantity of post and quantity of purchases.

According to the research conducted by You et al. (2015) on electronic word-of-mouth elasticity the more products a customer has to choose from leads to a decrease in the eWOM elasticity. In addition to their findings, a visible growth in an industry does not lead to bigger eWOM volume or valence elasticity. The review volumes on independent sites are higher compared to the review sections on retailers' sites. On the other side, these ratings have a little effect on products which cannot be tried (You et al., 2015). Along with the volume or valence of the information provided, the source credibility is a third element which influences the eWOM (López \& Sicilia, 2014). Social media sites, such as Facebook, is expected to encourage the users interact since the communication centrally plays back and forth between the users (Haigh, 2014). The work of Landsbergen (2010) has extended this notion with the addition of Twitter.

Yoo \& Gretzel (2008) conducted a Web-based overview utilizing an internet based shopper panel and it led to explore customers' inspirations to compose online travel reviews. Estimation scales to gauge the inspirations to contribute online travel surveys were produced and tried. The outcomes demonstrate that individuals who review their travel experience are for the most persuaded by helping a travel specialist co-op, attentiveness toward different buyers, and requirements for self-improvement. Expressing the displeased emotions through postings is not seen as an essential reason. Noteworthy contrasts in motivations were found for gender and salary level however not for age, education, youngsters in family unit, and marital status. Gender contrasts were found for the intentions of positive self-upgrade, venting negative sentiments and practicing aggregate power, along with providing support the firm. The outcomes show that females are more propelled by having the capacity to help the firms through their comments and by experiencing positive self-upgrade. On the other hand, inspirations of venting negative emotions and practicing aggregate power are higher for male online shoppers.

The study of Gomez \& Soto (2011) had an aim of understanding whether or not the Puerto Rican companies are using their social media platforms to enhance their relationship with their customers. The study was comprised of 400 local companies. The results of their study demonstrated how the local firms were failing to use their social media platforms by underestimating the possible reach they could gain if they were to put weight on this strategy. The research of Tewes (2016) demonstrates the importance of a two-way communication in professional sports organizations. The study examined the Twitter accounts of professional sports organizations. Their approach was divided into two: one being the content of the Twitter accounts and the other being 17 California organizations in the related field. The findings showed that the majority of the professional sports organizations do use a two-way communication in order to create a beneficial relationship. 
The work of Toppi, Ulkuniemi, Saraniemi, \& Malaska (2012) had focused on narrowing down the communication of the companies into industrial markets only. They have conducted a qualitative research by using some of the top social media sites and have reached to existing industrial companies. Their results have proven that social media marketing does increase the demand to shop in readers. In addition, they saw how this strategy had led even the customer's customer to shop online. Thus, the following hypothesis is formulated:

H2: Bidirectional communication on social media has a positive effect on the purchase decision.

A significant difference exists between the dissemination of positive and negative WOM (Hornik et al., 2015). The negative WOM lasts for a longer period of time with more detail given by dissatisfied customers. Additionally, the readers of the reviews tend to believe in the negative information more than the positive comments. The e-WOM influence of the consumer depends on his/her Internet experience (López \& Sicilia, 2014).

The cross-cultural study made between Mainland China and Taiwan (Chao \& Chen, 2016) had the purpose to answer the question on whether the expertise of either the reader or the commenter had an impact on the purchase decision. In other words, their study not only focused on the information provider but additionally the readers' background as well. The two factors were approached separately and it was found that respondents from Taiwan are more likely to be effected by the expertise of the commenter. When the analysis on the importance of the readers' background was made, the paper indicated how the expertise of the person receiving the comment is more important in Mainland China. Their study proved how different approached must be made based on the nationality and showed the changing perspectives of the two participating nationalities.

\subsection{Motives Affecting the Decision Making Process}

The research of Lin et al. (2013) has shown that consumer's turn to the internet when they are having doubts on purchasing a certain good or not. The decision making process is affected by the amount of comments posted and whether or not the individual writing the comment has good knowledge about the product. In addition, the quality is another factor affecting the buyer. Customers are more likely to purchase when the comments are based on facts and when they are easy to understand. Consumers who are searching for attention tend to more frequently post comments online than the ones who have different intentions, thus play the influential role (Cheung et al., 2012). While electronic word-of-mouth has a direct effect on the purchasing intentions, if the consumer puts his/her trust first then, eWOM has an indirect impact on the purchase (See-To \& Ho, 2014).

The confidence of the consumer increases depending on the expertise of the writer and the purpose of the research (Chang et al., 2010). The research of Chang et al. concluded that while the writer's expertise and own experience has an impact on the electronic word-ofmouth, the consumers own experience plays the essential role during the purchase decision. Furthermore, consumers who already have experience with particular brands are less likely to be effected by the opinions or actions of others (Cheung et al., 2012).

\subsection{WOM in Social Media}

Companies can develop and form their brand equity by using eWOM via social media context (Severi et al., 2014). The communication channel of electronic word-of-mouth can be used with the advertising strategy of the company. The essential part is for the marketer to transfer the message at the right time and right place since the receivers will be the opinion leaders in 
the future. According to Diffley et al. (2011) ads posted by firms on social network sites is probable to be overlooked by the individuals because these advertisements are created by the firm, and in this way seen as deceitful. Customers tend to look for data about items on discussion platforms (Cheong \& Morrison, 2008). They find these platforms reliable because the comments are written by the users themselves.

When it comes to twitter, tweets with pictures are more likely to be retweeted and favorited by clients (Alboqami et al., 2015). The visible growth in the amount of retweets due to the pictures could be credited to the acknowledgment component. Moreover, the findings of the research demonstrated that data about the items or services fundamentally influence shoppers' motive to embrace eWOM. Readers give careful consideration to posts and tweets that give data about the item or service. When companies engage, associate with clients and reply to them, the possibility of the customer to adopt electronic word-of-mouth grows. Users are more likely to connect further if they are replied directly via Twitter.

Kim et al. (2014) emphasizes how the degree of relationship the consumer has with the brand affects his/her tendency to retweet about the product. This behavior is mostly due to the person identifying him/herself with the brand. The retweets increase if the consumer is following the product's brand page. As the number of retweets increase, the consumer builds a trust toward the brand itself. Thus, Twitter plays the part of tool in relationship management. Allowing companies to easily reach out to the target and convey their messages.

The work of Eisingerich et al. (2015) focuses on the differences that exist between traditional word-of-mouth and social media word-of-mouth. Consumers are less willing comment about products because of the perceived social risk of WOM in social media settings. This situation is visible even for their favorite brands. This risk is explained by the fact that the reviews are open to a broader audience. Furthermore, these comments are read by people who are unknown to the writer which causes more stress. On the other side, consumers are more willing to provide feedback using traditional word-of-mouth.

The analyses of $\mathrm{Hu}$ (2015) pointed out that on Twitter, when it comes to choosing which products to buy individuals by far rely on the comments and reviews which family and friends give them. The research showed that news associations and brands are the second and third dependable sources; while government officials on Twitter are considered the least trustworthy. The amount of trust an individual has on someone's opinion changes from product to product. For instance, when individuals were not sure on which product to buy, the apparent validity of entertainment stars was higher when they expected to purchase an economical product than a costly one. Nevertheless, paying little mind to the item category, family and friends were the most dependable ones and legislators were the minimum credible sources on Twitter. Likewise, the strength of relationship between the sender and the receiver sets the level of trust the reader has (Koo, 2016).

Supporting the statement of Hu (2015), Coulter \& Roggeveen (2012) have also pointed out that source credibility is a critical factor while deciding on the viability of a persuasive communication. Likewise, as with different types of e-WOM, their research showed that item page content seemed, by all accounts, to be the essential driver as far as moving purchasers along the chain of being aware of the product to liking it. The undeniable ramifications for advertisers are to keep up a "solid" network page by posting essential and applicable item information. Additionally, as with different types of e-WOM, the receivers of the message will probably navigate to the proposed item page if the message piqued their interest. 
Even though source expertise is a crucial factor in the decision making, the trustworthiness of the writer is the variable which allows the reader to continue with the purchase (O'Reilly, MacMillan, Mumuni \& Lancendorfer, 2016). The reader does not care about the level of knowledge the commenter has if she or he sees him as an unreliable person. Consumers or the readers of the comment come to a conclusion based on the approach of the writer. Certain phrases which give the impression of marketing techniques are immediately ignored and never taken as a genuine comment with the intentions to help the reader.

The research of Mohammed (2016) was conducted in the field of tourism. The sample consisting of 216 tourists were asked about the importance of eWOM before they decide on their vacation spot. The study showed that there is a relation between destination trust and travel intention. In addition, the comparison between the genders demonstrated that travel intention plays a bigger role for women than men. The most important factor influencing the travelers are found to be knowledge the writer has about the place he/she has visited (Coursaris, Osch \& Albini, 2017). Since no boundaries exist in terms of who can write a comment, the reader has to decide on whether or not the commenter is someone they should trust (Atika, Kusumawati \& Iqbal, 2017). If the reader believes that the commenter is an expert than he/she will finish with the purchase of the product/service.

The content quality, popularity, and engaging quality fortify convenience and inclination on social media sites. Fans trust that valuable posts address individual needs, have clear depictions, or get positive remarks. Nevertheless, comments and images play a crucial role when fans have to choose among multiple sites. In addition, the expert's level of expertise has an impact on the consumer's wish to like and share. While posting images has the possibility to draw lower level fans, posts created by experts has a higher chance to draw in higher level fans (Chang \& Lu, 2015). Based on the findings of Hoffman \& Daugherty (2013), the communication ties between firm and consumers are not merely up to the content, the delivery effectiveness is just as important. Apparently, customers give their time into creating eWOM via social media since they wish to have any kind of effect by impacting product awareness and choices made by different purchasers. Therefore, the following hypothesis has been derived:

H3: The level of writer's expertise positively affects the purchase decision.

\subsection{Actions Taken by Companies}

Previous research has illustrated that the firms which have improved their sales by increasing their efforts toward digital marketing channels have all gone through four stages (Edelman, 2010). Initially, companies connect their digital activities with their customers. This step secures the product purchase. Second, the marketers create brand awareness by using content which enables the customers to easily form a visual of the product. Third, they start looking from the perspective of the media publishers because the number of content which they have to manage increases. The final step is planning out how to piece the obtained data together for future use.

The consumers are more likely to embrace another company when adequate amount of information is provided online (Jalilvand et al. 2011). The research of Jalilvand et al. (2011) specifies that companies have created a customer review section in order to compensate the declining habit of walking in stores and talking with the salespeople for product information. As the number of customers who are exposed to online stores increases, so does their curiosity to learn more about the product. Their intentions to purchase increase as the number 
of comments increases (Lin et al. 2013). Due to these reasons, electronic word-of-mouth is a crucial part of the brands in today's electronic environment.

In their work, Jansen et al. (2009) has concluded that micro blogging is a powerful tool companies can use while building up their brand strategy. Firms can obtain crucial knowledge about their customer base since customers use natural language expressions and genuinely state their experience with the products or service. Customers' brand perception and purchasing decisions are highly affected by the posts of others. These social networking sites bring the opportunity for the firms to build strong relations with their customers. Furthermore, micro blogging creates a near real time connection with the customers. Meaning that, firms have a constant stream of information flow which can assist them in finding the right branding strategy.

Aggarwal et al. (2012) have researched the effect of electronic word-of-mouth from the venture financing field. There results show that the impact of negative electronic word-ofmouth is greater than the impact of positive eWOM. The posts made on highly visited blog sites boost the likelihood of the ventures to achieve higher funding amounts and valuations. What shouldn't be forgotten is that this technique of posting on blog sites to catch the attention of possible VCs has a limited affect. Moreover, referrals are essential for getting higher funding amounts and valuations from VCs because they simply give priority to the people who they can trust first (Aggarwal et al. 2012). In other words, the source of the electronic word-of-mouth is crucial in the decision making process of the VCs.

The researches of See-To \& Ho (2014) show that, the purchasing intentions of a potential customer can be altered using numerous eWOM channels. These channels may be (i) direct impact; (ii) moderates by different aspects of trust (i.e., institutional-based trust and trusting beliefs); and (iii) moderates by the value co-creation process. In particular, firms may use the trust gained though electronic word-of-mouth to understand how they could better utilize the social network sites. Because of these channels, companies should use their online basis of communication to improve each step of their value co-creation process.

Star rating is one of the many ways users can spread their experience with a service. The study of Park (2017) focused on the role this technique plays in the restaurant business. The ratings were examined from restaurants located in London and New York. A total of 45 restaurants were analyzed. The findings showed that the moderate ratings were the effective ones. Since readers need clear and reasoned ratings, the ones which were rated very low or very high were seen more helpful. The work of Schuckert, Liu, \& Law (2016) had also focused on the importance of ratings. Their study was covered the online badges and ratings along with it. In contrast to the findings of Park (2017) their results indicated that only low ratings are considered reliable. The users wanting to reflect their satisfaction were abstaining.

The work of Kwok, Kwok, Xie, \& Xie (2016) examined the role of manager reviews for hotels. The purpose of the study was to understand if the reviews coming from the hotel managers were positively affecting the possible guests. The sample consisted of over a thousand hotels and more than ten thousand managers. Their findings state that reviews given from the managers and the previous guests are considered valuable. The extent to which the reviews are considered trustworthy varies based on the duration of the membership and how much the reviewer has actually traveled. 
Park et al. (2007) emphasizes how electronic word-of-mouth has two different roles of either becoming the channel for obtaining information or a sign of product popularity. However, the extent to which the consumer is affected by one of these roles is based on the consumer's intention. Consumers tend to care more about reading the comments which give more clues about the product when their intentions to buy are high. On the other hand, when their buying intentions are low, the quality of the comments is not a priority. In this case, consumers are merely interest in the popularity of the product in question. When the impact of the popularity factor is examined it has been found that there isn't a significant effect on the consumers (Romero, Galuba, Asur, \& Huberman, 2011). The mentioned literature has lead to the following hypothesis:

H4: The popularity of a product positively affects the purchase decision.

Based on the above literature about the varying factors affecting the consumers' purchase decision the conceptual framework of the present study was developed. Figure 1 presents the conceptual framework of this research.

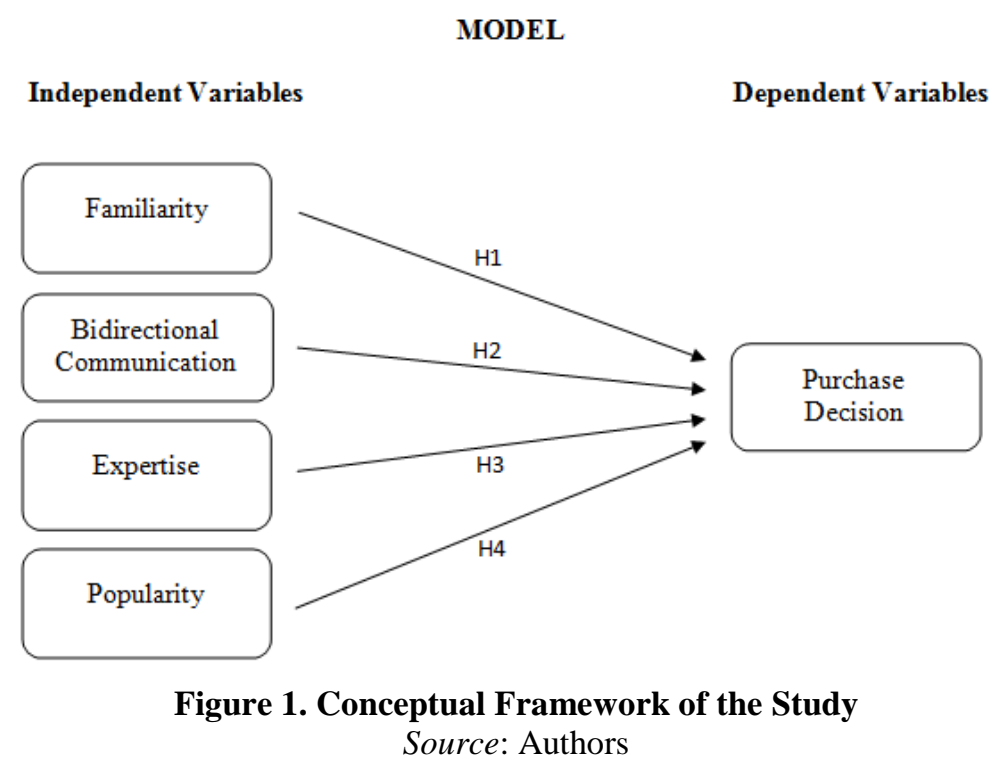

Together with hypothesis different research questions were developed for this study such as:

1. Is there a difference in the effectiveness of the familiarity of the eWOM source between Romanian and Bosnian students?

2. Is there a difference in the effectiveness of bi-directional communication on social media between Romanian and Bosnian students?

3. Is there a difference in the effectiveness of the writer's expertise on the purchase decision between Romanian and Bosnian students?

4. Is there a difference in the effectiveness of the popularity of a product on the purchase decisions between Romanian and Bosnian students?

\section{METHODOLOGY}

Quantitative method of research was used for this study. It enabled us to generalize the findings from our sample of Bosnian and Romanian students. Since quantitative research was chosen, this research involved structured techniques such as online questionnaires and mobile surveys. 
According to the study of Perrin (2015), 90\% of the teenagers from the ages 18 to 29 have a social media presence. In this manner, the utilization of university students was considered suitable as the sample group for the study.

\subsection{Sampling Procedure}

Since this study centers upon the heavy users of social media as a source of eWOM, university students were the sample of this study. The research was conducted in Sarajevo Bosnia and Herzegovina and Timisoara Romania. At total of 400 students filled out the questionnaire. While 200 of the replies came from Sarajevo, 200 of them were attained from Timisoara. The majority of the students were either Romanian or Bosnian. Female students comprised more than half of the total responses. The average age of the university students which participated were 18 to 24 .

\subsection{Questionnaire Design}

The questionnaire was formed using Google forms. It began with an introductory paragraph explaining the reason for conducting the research and what their contributions meant for the data gathering. Twenty straight forward questions were design and all besides the demographic questions were 5-point Likert scale based. Each question was mandatory to reply while confidentiality was promised. The survey had 6 short sections. The first four questions were asked to understand the demographic background of the respondents; such as their age and nationality. The second section was used to measure the impact of commenter familiarity and whether readers see known source as more valuable. The third section focused on comprehending the importance on bidirectional communication. The fourth section comprised of the expertise factor. Knowing that only some of the comments are written by experts this section aimed to analyze the significance of the writer's background. The fifth section asked the frequency to purchase a product because of its popularity. The final section consisted of questions directed to understand your purchase behavior based on the comments on social media. A title and description for each section were added in order to ease the understanding of the sections. This also helped the respondent clear any questions regarding the aim of the research.

The item measurements for this study were gathered from various previous researches. The familiarity variable was derived from researches such as Goodrich \& De Mooij (2014), Hu (2015) and Erkan \& Evans (2016). Some of the references which the bi-directional communication item was obtained from are Kietzmann \& Canhoto (2013), Haigh (2014) and Tewes (2016). The item for level of writer's expertise can be seen in Chang et al. (2010), Chao \& Chen (2016) and Atika, Kusumawati \& Iqbal (2017). Finally, research on the effect of popularity on decision making can be found in Lin et al. (2013), Schuckert, Liu, \& Law (2016) and Park (2017).

\subsection{Data Collection}

The data collection was made by using an online survey created in Google Forms. The students were reached by using their student email addresses and Facebook groups created by different departments. Additionally, door-to-door survey approach was used in Timisoara in order to reach the planned number of responses. The approximate time to complete the survey was 3 minutes. The survey was conducted from February 10, 2017 till April 13, 2017.

Online questionnaires were preferred because of its efficient in time and cost. An additional factor was the target accessibility. The students could easily fill out and send the survey on their mobile phones. When this data collection method is used, the respondent has the opportunity to choose when to fill in the survey, at their own pace. The room for mistake is significantly diminished with online surveys since students enter their responses 
straightforwardly into the system. The possibility of entering wrong data is high when traditional methods are used because the surveyor has to repetitively enter data.

The low response rate among Bosnian students shifted the data collection method from online surveys to printing them and handing them out during classes. This speeded the data collection process and guaranteed the aimed response rates. In the end, 200 respondents were reached. This number created an equal distribution of students studying in either of the two countries.

\subsection{Data Analysis}

To test the hypotheses, the data were analyzed using SPSS 18.0. First, the descriptive statistics were shown to reflect the demographic profile of the respondents as well as to illustrate the different preferences between Romanian and Bosnian students for certain questions. Second, a reliability analysis was conducted to ensure consistency of the survey questions. Third, independent sample t-test was used to test each hypothesis as to what influences the purchase decisions based on eWOM on social media. The t-tests provided the mean differences between the two sample groups. Fourth, multiple regression analysis was conducted to predict the scores for the decision making variable if we were to use familiarity, bi-directional communication, expertise and the popularity factors.

\section{RESULTS}

\subsection{Descriptive Statistics}

An online survey was conducted from February 10, 2017 to April 13, 2017 to collect data. A total of 262 participants responded to the online questionnaire. The remaining 138 of them were printed and handed out to students studying in Sarajevo. Out of the 400 responses, 74 of them were foreign students studying either in Romania or Bosnia and Herzegovina. 172 of the responses came from Romania and 154 of them were obtained in $\mathrm{B} \& \mathrm{H}$. The pie chart below demonstrates the percentage distribution of the respondents.

Table 1. Demographic Profile of Respondents

\begin{tabular}{|l|l|c|c|}
\hline \multicolumn{2}{|c|}{ Demographic Variable } & Frequency (n) & Percent (\%) \\
\hline \multirow{4}{*}{ Gender } & Male & 173 & 43,3 \\
\cline { 2 - 4 } & Female & 227 & 56,8 \\
\cline { 2 - 4 } & Total & 400 & 100 \\
\hline \multirow{5}{*}{ Age } & Below 18 & 7 & 1,8 \\
\cline { 2 - 4 } & $18-24$ & 367 & 91,8 \\
\cline { 2 - 4 } & 25 and Above & 26 & 6,5 \\
\cline { 2 - 4 } & Total & 400 & 100 \\
\hline \multirow{5}{*}{ Eationality } & Bosnian & 154 & 38,5 \\
\cline { 2 - 4 } & Romanian & 172 & 43 \\
\cline { 2 - 4 } & Other & 74 & 18,5 \\
\cline { 2 - 4 } & Total & 400 & 100 \\
\hline & High School & 200 & 50 \\
\cline { 2 - 4 } & Undergraduate & 164 & 41 \\
\cline { 2 - 4 } & Master & 34 & 8,5 \\
\cline { 2 - 4 } & PhD & 2 & 0,5 \\
\cline { 2 - 4 } & Total & 400 & 100 \\
\hline
\end{tabular}


Table 1 shows that there are a total of 400 respondents, 227 of them female and 173 of them male. The majority of the survey has been filled out by females with a $56.8 \%$ of response rate, leaving the males $43.3 \%$ out of the total. 7 respondents are below the age of 18,367 of them are between the ages of $18-24$ and 26 of them are 25 or above. These results lead to the conclusion that most of the respondents were between the ages 18-24, making up $91.8 \%$ of the surveyors. Based on the findings of the table, 154 of the respondents are Bosnian and 172 of them are Romanian and $74 \%$ of them are from an unlisted country. The percentages are $38.5,43.0$ and 18.5 respectively. Out of the total 400 respondents, half of them have finished high school and are studying undergraduate. 164 respondents have finished undergraduate, 34 of them have finished their master's degree and only 2 have finished their $\mathrm{PhD}$. The percentages based on the education levels of the respondents are 50.0, 41.0, 8.5 and 0.5, respectively.

\subsection{Reliability Testing}

For the reliability test Cronbach's alpha was analyzed. It is $\mathbf{0 . 8 2 8}$, which indicates high overall internal consistency among the sixteen items representing the factors affecting the consumers' purchase decision.

\subsubsection{T-Tests}

Independent sample t-tests have been used in order to answer research questions that are presented above. This allowed the study to present whether or not the difference between the two samples of Bosnian and Romanian students are statistically significant from one another.

Table 2. Independent Samples Test of Nationality and the Familiarity of the Commenter on SM

\begin{tabular}{|c|c|c|c|c|c|c|c|c|c|c|}
\hline & & \multicolumn{2}{|c|}{$\begin{array}{l}\text { Levene's Test } \\
\text { for Equality of } \\
\text { Variances }\end{array}$} & \multicolumn{7}{|c|}{ t-test for Equality of Means } \\
\hline & & $\mathrm{F}$ & Sig. & \multirow[t]{2}{*}{$\mathrm{t}$} & \multirow[t]{2}{*}{ df } & \multirow[t]{2}{*}{$\begin{array}{l}\text { Sig. (2- } \\
\text { tailed) }\end{array}$} & \multirow[t]{2}{*}{$\begin{array}{c}\text { Mean } \\
\text { Difference }\end{array}$} & \multirow[t]{2}{*}{$\begin{array}{l}\text { Std. Error } \\
\text { Difference }\end{array}$} & \multicolumn{2}{|c|}{$\begin{array}{l}\text { 95\% Confidence } \\
\text { Interval of the } \\
\text { Difference }\end{array}$} \\
\hline & & & & & & & & & Lower & Upper \\
\hline \multirow[t]{2}{*}{ Familiarity } & \begin{tabular}{|l} 
Equal \\
variances \\
assumed
\end{tabular} & 2.069 & .151 & -2.905 & 324 & .004 & -.19839 & .06829 & -.33273 & -.06405 \\
\hline & \begin{tabular}{|l} 
Equal \\
variances \\
not assumed \\
\end{tabular} & & & -2.885 & 307.137 & .004 & -.19839 & .06876 & -.33369 & -.06309 \\
\hline
\end{tabular}

Table 2 presents the descriptive statistics for the two test values. The mean values of the two nationalities indicate that Romanian students $(M=3.5487)$ are more affected by the familiarity of the eWOM source than Bosnian students $(M=3.7471)$. The table above presents the $t$-test results. Since $0.151>0.05$, 'equal variances assumed' is taken into consideration and the $t$ value is $\mathbf{- 2 . 9 0 5}$ with 324 degrees of freedom. At a $\mathbf{0 . 0 5}$ significance level, the p-value is $\mathbf{0 . 0 0 4}$. Also, the $95 \%$ confidence interval information shows that the null hypothesis value (i.e., zero) does not fall within this interval (Lower $=-.33273$, Upper $=-.06405$ ). Therefore we can reject the null hypothesis stating that there is no difference between Bosnian and Romanian students when it comes to being affected by the familiarity of the eWOM source. We can conclude that there is a statistically significant amount of difference between Bosnian students and Romanian students when the eWOM source is familiar to the reader of the comment. 
Table 3. Independent samples test of Nationality and the Bi-directional Communication with the Commenter on SM

\begin{tabular}{|c|c|c|c|c|c|c|c|c|c|c|}
\hline & & \multicolumn{2}{|c|}{$\begin{array}{c}\text { Levene's Test } \\
\text { for Equality of } \\
\text { Variances } \\
\end{array}$} & \multicolumn{7}{|c|}{ t-test for Equality of Means } \\
\hline & & \multirow[t]{2}{*}{$\mathrm{F}$} & \multirow[t]{2}{*}{ Sig. } & \multirow[t]{2}{*}{$\mathrm{t}$} & \multirow[t]{2}{*}{ df } & \multirow[t]{2}{*}{$\begin{array}{l}\text { Sig. } \\
(2- \\
\text { tailed })\end{array}$} & \multirow[t]{2}{*}{$\begin{array}{c}\text { Mean } \\
\text { Difference }\end{array}$} & \multirow[t]{2}{*}{$\begin{array}{l}\text { Std. Error } \\
\text { Difference }\end{array}$} & \multicolumn{2}{|c|}{$\begin{array}{l}\text { 95\% Confidence } \\
\text { Interval of the } \\
\text { Difference }\end{array}$} \\
\hline & & & & & & & & & Lower & Upper \\
\hline \multirow[t]{2}{*}{$\begin{array}{l}\text { Bi-directional } \\
\text { Communication }\end{array}$} & $\begin{array}{l}\text { Equal } \\
\text { variances } \\
\text { assumed } \\
\end{array}$ & 3.184 & .075 & -2.738 & 324 & .007 & -.23372 & .08536 & -.40164 & -.06579 \\
\hline & $\begin{array}{l}\text { Equal } \\
\text { variances } \\
\text { not } \\
\text { assumed } \\
\end{array}$ & & & -2.723 & 310.298 & .007 & -.23372 & .08583 & -.40260 & -.06484 \\
\hline
\end{tabular}

Source: Author

Table 3 gives the descriptive statistics for the two test values. The mean values of Bosnian and Romanian students are $\mathrm{M}=2.8593$ and $\mathrm{M}=3.0930$, respectively. Meaning that, the level of importance attached to bi-directional communication on social media for Romanian students is higher than Bosnian students. Table 3 shows that the Levene statistic is $\mathrm{F}=3.184$ and the corresponding significance level is large $(.075>0.05)$. Thus we can use equal variances assumed $t$ test statistic to evaluate the hypothesis. The results of the $t$ test present us that the $t$ value is $\mathbf{- 2 . 7 3 8}$ with 324 degrees of freedom. Additionally, the $95 \%$ confidence interval information shows that the null hypothesis value does not fall within this interval (Lower = -.40164, Upper $=-.06579$ ). Since $\mathbf{. 0 0 7}<\mathbf{0 . 0 5}$, we can reject the null hypothesis stating that there is no significant amount of difference between Romanian and Bosnian students in the effectiveness of bi-directional communication on social media.

The mean values presented in Table 4 show that the expertise of the commenter has a higher impact on Romanian ( $M=3.4554)$ students than Bosnian $(M=3.0606)$ students. When we examine table 4 we can see that the Levene test statistic is $\mathrm{F}=4.701$ and the corresponding significance level is .031 . Since $.031<0.05$, equal variances not assumed test statistic will be used to evaluate the third hypothesis of this paper. The $t$ value for the equality of means is -4.974 with 300.199 degrees of freedom. At a $\mathbf{0 . 0 5}$ significance level, the p-value is $\mathbf{0 . 0 0 0}$. The $95 \%$ confidence interval information found in the table supports the significance test results.

Table 4. Independent Samples Test of Nationality and the Expertise of the Commenter on SM

\begin{tabular}{|c|c|c|c|c|c|c|c|c|c|c|}
\hline & \multicolumn{2}{|c|}{$\begin{array}{c}\text { Levene's Test } \\
\text { for Equality of } \\
\text { Variances } \\
\end{array}$} & \multicolumn{7}{|c|}{ t-test for Equality of Means } \\
\hline & & \multirow[t]{2}{*}{$\mathrm{F}$} & \multirow[t]{2}{*}{ Sig. } & \multirow[t]{2}{*}{$\mathrm{t}$} & \multirow[t]{2}{*}{ df } & \multirow[t]{2}{*}{$\begin{array}{l}\text { Sig. (2- } \\
\text { tailed) }\end{array}$} & \multirow[t]{2}{*}{$\begin{array}{c}\text { Mean } \\
\text { Difference }\end{array}$} & \multirow[t]{2}{*}{$\begin{array}{l}\text { Std. Error } \\
\text { Difference }\end{array}$} & \multicolumn{2}{|c|}{$\begin{array}{l}95 \% \text { Confidence } \\
\text { Interval of the } \\
\text { Difference }\end{array}$} \\
\hline & & & & & & & & & Lower & Upper \\
\hline \multirow[t]{2}{*}{ Expertise } & $\begin{array}{l}\text { Equal variances } \\
\text { assumed }\end{array}$ & 4.701 & .031 & -5.021 & 324 & .000 & -.39482 & .07863 & -.54951 & -.24013 \\
\hline & $\begin{array}{l}\text { Equal variances } \\
\text { not assumed }\end{array}$ & & & -4.974 & 300.199 & .000 & -.39482 & .07938 & -.55104 & -.23860 \\
\hline
\end{tabular}

Source: Author

We can say that there is a significant amount of difference between Romanian and Bosnian students in terms of the effectiveness of the writer's expertise on the purchase decision. In other words the null hypothesis stating that there is no difference between the two test values is rejected. 
Table 5. Independent sSamples Test of Nationality and the Popularity of the Product on SM

\begin{tabular}{|c|c|c|c|c|c|c|c|c|c|c|}
\hline & \multicolumn{2}{|c|}{$\begin{array}{c}\text { Levene's Test } \\
\text { for Equality of } \\
\text { Variances }\end{array}$} & \multicolumn{7}{|c|}{ t-test for Equality of Means } \\
\hline & & \multirow[t]{2}{*}{ F } & \multirow[t]{2}{*}{ Sig. } & \multirow[t]{2}{*}{$\mathrm{t}$} & \multirow[t]{2}{*}{ df } & \multirow[t]{2}{*}{$\begin{array}{l}\text { Sig. (2- } \\
\text { tailed) }\end{array}$} & \multirow[t]{2}{*}{$\begin{array}{c}\text { Mean } \\
\text { Difference }\end{array}$} & \multirow[t]{2}{*}{$\begin{array}{l}\text { Std. Error } \\
\text { Difference }\end{array}$} & \multicolumn{2}{|c|}{$\begin{array}{l}\text { 95\% Confidence } \\
\text { Interval of the } \\
\text { Difference }\end{array}$} \\
\hline & & & & & & & & & Lower & Upper \\
\hline \multirow[t]{2}{*}{ Popularity } & \begin{tabular}{|l} 
Equal \\
variances \\
assumed
\end{tabular} & .462 & .497 & -4.475 & 324 & .000 & -.39575 & .08843 & -.56972 & -.22178 \\
\hline & \begin{tabular}{|l|} 
Equal \\
variances not \\
assumed
\end{tabular} & & & -4.460 & 314.653 & .000 & -.39575 & .08873 & -.57033 & -.22117 \\
\hline
\end{tabular}

Source: Author

The data given in table 5 shows that the effectiveness of the popularity of a product on the purchase intentions is higher for Romanian students $(\mathrm{M}=3.4845)$ when compared to Bosnian students $(M=3.0887)$. Since the significance level of Levene statistics is greater than 0.05 , 'equal variances assumed' is taken into consideration. Based on this selection, the t value is $\mathbf{- 4 . 4 7 5}$ with 324 degrees of freedom. At a $\mathbf{0 . 0 5}$ significance level, the p-value is $\mathbf{0 . 0 0 0}$ and the $95 \%$ confidence interval is Lower $=-.56972$ and Upper $=-.22178$. Therefore we can reject the null hypothesis stating that there is no difference in the effectiveness of the popularity of a product on the purchase decision between Romanian and Bosnian students. We can conclude that the popularity of a product does affect the purchase intention of Bosnian and Romanian students at a statistically significant level.

\subsection{Hypotheses Testing}

The main analysis we used is multiple linear regression. By using selecting this approach, we presented the information on how well we can predict the scores for the decision making variable if we were to use familiarity, bi-directional communication, expertise and the popularity factors all at the same time.

Table 6. $\mathrm{R}$ and $\mathrm{R}$ Square for the Model

\begin{tabular}{|l|l|r|r|}
\hline Multiple R & & & 0.571 \\
\hline Coefficient of Determination $\left(\mathrm{R}^{2}\right)$ & & & 0.327 \\
\hline Adjusted $\mathrm{R}^{2}$ & & & 0.320 \\
\hline Standard error of the estimate & & & 0.65195 \\
\hline
\end{tabular}

Table 7. Reports on Analysis of Variance

\begin{tabular}{|l|r|r|r|r|r|}
\hline & \multicolumn{1}{|c|}{ Sum of Squares } & \multicolumn{1}{c|}{ df } & Mean Square & \multicolumn{1}{c|}{ F } & Sig. \\
\hline Regression & 81.419 & 4 & 20.355 & 47.888 & 0.000 \\
\hline Residual & 167.892 & 395 & 0.425 & & \\
\hline Total & 249.311 & 399 & & & \\
\hline \multicolumn{7}{|c|}{ Source: Author }
\end{tabular}

Table 6 shows that the value of $\mathrm{R}^{2}$ is $\mathbf{. 3 2 7}$, which tells that popularity, expertise, familiarity and bidirectional communication account for a 32.7\% effect on customers purchase decision. The results of table 22 tell us that $F$ is $\mathbf{4 7 . 8 8 8}$, which is significant at $\boldsymbol{p} \square \square . \mathbf{0 5}$. So we can reject the null hypothesis stating that popularity, expertise, familiarity and bidirectional communication does not have a relation with making a purchase decision. 
Table 8. Coefficients

\begin{tabular}{|c|c|c|c|c|c|c|}
\hline & \multirow{2}{*}{ Model } & \multicolumn{2}{|c|}{ Unstandardized Coefficients } & \multirow{2}{*}{$\begin{array}{c}\begin{array}{c}\text { Standardized } \\
\text { Coefficients }\end{array} \\
\text { Beta }\end{array}$} & \multirow[t]{2}{*}{$\mathrm{t}$} & \multirow{2}{*}{ Sig. } \\
\hline & & $\mathrm{B}$ & Std. Error & & & \\
\hline \multirow[t]{5}{*}{1} & (Constant) & .719 & .219 & & 3.279 & .001 \\
\hline & Familiarity & .379 & .059 & .298 & 6.375 & .000 \\
\hline & $\begin{array}{l}\text { Bidirectional } \\
\text { Communication }\end{array}$ & 201 & .049 & .198 & 4.108 & .000 \\
\hline & Expertise & -.034 & .052 & -.031 & -.657 & .511 \\
\hline & Popularity & .268 & .044 & .277 & 6.020 & .000 \\
\hline
\end{tabular}

Source: Author

The table above summarizes the results of our regression equation. It shows us the standardized Beta coefficient between the predictor variables and the dependent variable which is decision making. When we look at the Sig. column the findings are as follows:

At a 0.05 significance level, the independent variables familiarity, bidirectional communication and expertise are significantly different from 0 because their $p$-values are 0.000 , which is smaller than 0.05 .

At a 0.05 significance level, the independent variable expertise is not significantly different from 0 because its p-value is .511 , which is larger than 0.05 .

In sum, the familiarity of the eWOM source, ability to conduct a two-way communication and the popularity of a product/service on social media plays a significant role for both groups. On the other hand, the expertise of the commenter is found to be insignificant for the two groups. This makes the expertise variable the only tested independent variable found to not have an influence on Romanian and Bosnian students.

Table 9. Summary of Hypotheses Test Result

\begin{tabular}{|l|c|}
\hline \multicolumn{1}{|c|}{ Research Hypothesis } & Outcome \\
\hline H1: The familiarity of the eWOM source positively affects the purchase decision. & Support \\
\hline $\begin{array}{l}\text { H2: Bidirectional communication on social media has a positive effect on the purchase } \\
\text { decision. }\end{array}$ & Support \\
\hline H3: The level of writer's expertise positively affects the purchase intention. & Reject \\
\hline
\end{tabular}

Source: Author

\section{DISCUSSION}

This study set out to explore the factors affecting the purchase decisions based on eWOM in social media. More precisely, it focused on the effects of the eWOM source familiarity, bidirectional communication on social media, effect of the writer's expertise and the popularity of a product/service. 
The data for the study was gathered in two different countries. One being Romania (Timisoara) and the other being Bosnia and Herzegovina (Sarajevo). This enabled us to compare the two student groups studying in both countries. In the end, we found out whether or not the two samples were putting the same amount of importance on the previously mentioned independent variables. In addition, by looking at the mean values, we presented which nationality attaches more importance on each of the four independent variables.

Even though 200 responses from each country were collected, the international students were omitted during the analysis part of the study. This resulted in excluding a total of 74 students and left us 326 suitable students. The majority of the responses came from female student which accounted for $56.8 \%$. As expected, the largest age range comprising was $18-24$. When asked about the educational level of the respondents exactly half of the students replied that they had finished high school and were currently undergraduate students.

The descriptive analysis shows that the four variables do not possess the same level of importance. The results indicate that for both nationalities the familiarity variable plays the most important role out of the four. Social media users are prone to rely on comments they read from friends and other acquaintances. Becoming informed by someone who you know by first hand eliminates the doubt of reliability. On the hand, the opportunity to communicate with the writer of the comment is found to be the least important variable. This provides an understanding that both Romanian and Bosnian students are rarely the initiatives of communication to gain more information on a certain product/service on social media. When compared with the familiarity variable we understand that our sample takes cognizance of immediately concluding whether or not the comment is reliable and provides most of the information needed without the extra effort of contacting. The other two variables analyzed were expertise and the popularity of a product/service on social media. The results of both variables have shown that even though they are not considered to be as important as the familiarity variable. On the other hand, their roles aren't as small as being able to communicate with the commenter. That is to say, they fall in between the two.

The statistical analysis has proven that Romanian and Bosnian students show a significant difference in terms of source familiarity, bidirectional communication on social media and the popularity of a product/service. On the other hand, level of difference in terms of the effect of the writer's expertise was found to be insignificant. That is, the writer's expertise was the only variable which does not differ between Romanian and Bosnian students who have responded to the survey. When we look at the mean values of each variable and compare with the other nationality we can conclude that Romanian students have given more positive responses. This tells that they are more likely to be effected by each of the analyzed variable.

The findings of this paper are a mixture of agreement and disagreement with the previous literature. While the analysis of some variables are in line with the results of other researchers some show significant differences.

In terms of the familiarity variable, our findings are in line with numerous findings in the literature (Evans \& Erkan, 2014; Chu, 201; Hu, 2015; Moran \& Muzellec, 2017). Our results point out that comments coming from close friends and family are crucial factors shaping the decision making of the reader on social media. While firm-created content directly affects the consumer's behavior in terms of the brand, it doesn't change the consumers' understanding of brand equity. Firms can reach a wider audience by creating social media content. Hence, firms should find ways to draw in or urge purchasers to create content that shows how satisfied they 
are with the brand. In short, firms should not compete with user generated content but instead focus on spreading brand awareness (Schivinski \& Dabrowski, 2016).

The offline friend environment may have the highest trust but the social environment among friends rank higher than corporate communication (Pedersen, Razmerita, \& Colleoni, 2014). Themba \& Mulala (2013) have reported that opinion seeking behavior has an impact on consumers' purchase decision. Our findings share similarities with Buzzetto-More (2013) who had given weight to asking questions regarding the importance of comments on social media and its implications on the readers' decision making. The findings of their study proved that more than half of the participants make up their mind based on the comments of their friends, family and other acquaintances. In addition, it was seen that the consumers who are active users of social media recommend products/services on a regular basis.

The way buyers send and obtain data is evolving quickly. With the advanced technology right under our hands, customers have the wish to become a piece of the relationship in which they convey their thoughts and opinions about an organization or item (Amstein, 2010). They hope to have all time access to the organizations they have made purchases from. In order for this to possible, they need to have a two-way relationship in light of discussion. Consistent with the literature review, analysis suggests that the freedom to contact the commenter is a plus for the reader on social media. The possibility to contact the person who intrigued your interest by a post is found to have a significant impact on the reader's decision making.

In contradiction to the early findings of Cheung et al. (2012), our t-test results have proven that there is a significant amount of difference between Romanian and Bosnian students in terms of the effectiveness of the writer's expertise on the purchase decision. The part which conflicts with this statement is that the multiple regression analysis showed how the expertise variable does not have a relation with the decision making. On the other hand, the findings of Chen et al. (2016) demonstrate how a recommendation which comes from an expert has a positive effect on the reader. This notable aspect allows us to understand that further investigation on this topic should be made. Companies have the opportunity to increase the outcomes of their digital marketing channels by increasing their efforts in this field (Edelman, 2010).

Despite our results of popularity variable differing from earlier studies (Romero et al., 2011), they are consistent with those of (Park et al. 2007). Nearly half of the teens are reported to be using social media as their decision making source for a certain product/service (Lobaugh, Simpson, \& Ohri, 2015). Considerable attention must be pain when companies are searching for the right marketing opportunity. For managerial practice, the results suggest that the trending topics, discussions and the flock of web users concentrated on a certain topic should act as a signal and show the right path which was must be taken. This will ultimately generate leads and increase the significance of the company's social media platform. Social media has been utilized as an essential way for firms to impact purchasers' behavior. The impact is visible among the online shoppers because these individuals have the control of finding, creating, sharing, and dispersing their thoughts (Chen, Chen, \& Xu, 2016).

The ultimate aim of managers should be to utilize their social media marketing strategies to grasp the infinite pool of costumers' insights. The current study has proven the effect of nationality in all four of its independent variables. Meaning that the ideal mold of strategies should comprise of elements defining which nationalities put more trust in social media sites. The results demonstrated a pattern of Romanian consumers exhibiting more positive 
behaviors towards the comments posted. Given the fact that Romania is a more developed country and can provide better opportunities for its citizens could be factors outdoing the place social media occupies in the lives of Bosnian social media users. Even though managers are capable of filtering their target group, these methods could result in unsatisfactory levels of consumer bonding due to the fact that the certain national might not be placing a significant amount of importance to eWOM on his/her social media accounts. In order for managers to overcome this obstacle, they must examine their targets' nationality along with other demographic characteristics.

\section{CONCLUSION}

Electronic word-of-mouth is known to have a superior power over other various marketing strategies and advertisements. When this form of marketing strategy is used on social media sites a significant increase in its effect is clearly visible. Foremost attention should be paid on mastering the use of these platforms and creating a base for the social media users to engage and become a chain among the hundreds of comments and posts about a certain product/service. While countless variables play with the effectiveness of eWOM in social media, this paper focused on only four. The results of the statistical analysis have prolonged the list of sources which can be used in this area. It not only demonstrated how effective eWOM in social media is but also proved that its significance differs among Romanian and Bosnian students. This leads to the understanding that different nationalities place different importance on the comments they read on social media.

As previously stated the present study wanted to investigate the differences between Romanian and Bosnian students. I would like to point out that even though, based on the multiple regression analysis, the commenter's expertise variable was found to not have a relationship with the decision making variable, we cannot overlook the pattern. That is, this variable did not change the trend we could see when we look at the mean scores of each variable. Overall, Romanian students scored higher, more positive responses in each of the four variables. This shows that the single variable found not to have a relation with consumer's online decision making still possess a higher impact on Romanian students.

Having found that three out of the four independent variables have a significant effect on the decision making of the reader indicates that marketers have the opportunity to wisely shape their social media usage. They can reach their customers by studying the effective variables and thus conduct a successful marketing approach.

\section{REFERENCES}

Aggarwal, R., Gopal, R., Gupta, A., \& Singh, H. (2012). Putting money where the mouths are: The relation between venture financing and electronic word-of-mouth. Information Systems Research, 23(3-part-2), 976-992

Alboqami, H., Al-Karaghouli, W., Baeshen, Y., Erkan, I., Evans, C., \& Ghoneim, A. (2015). Electronic word of mouth in social media: the common characteristics of retweeted and favourited marketer-generated content posted on Twitter. International Journal of Internet Marketing and Advertising, 9(4), 338-358

Amstein, D. (2010). Engaging Consumers Through Social Media. Retrieved May 23, 2017, from http://midanmarketing.com/resources/whitepapers/wp-social-media.pdf

Atika, A., Kusumawati, A., \& Iqbal, M. (2017). The Effect of Electronic Word Of Mouth, Message Source Credibility, Information Quality on Brand Image And Purchase Intention. EKUITAS (Jurnal Ekonomi dan Keuangan), 20(1), 94-108 
Bandari, R., Asur, S., \& Huberman, B. A. (2012). The pulse of news in social media: Forecasting popularity. arXiv preprint arXiv:1202.0332

Beckmann, S. C., \& Bell, S. (2001). Viral Marketing= word-of-mouth marketing on the Internet?. In The 30th European Marketing Academy Conference, May 2001

Briggs, S. R., \& Cheek, J. M. (1986). The role of factor analysis in the development and evaluation of personality scales. Journal of personality, 54(1), 106-148.

Burtch, G., \& Hong, Y. (2014). What happens when word of mouth goes mobile?. Burtch, G., and Hong, Y.(2014) What Happens When Word of Mouth Goes Mobile

Buzzetto-More, N. (2013, July). Social media and prosumerism. In Proceedings of the Informing Science and Information Technology Education Conference (pp. 67-80). Informing Science Institute

Coursaris, C., Osch, W., \& Albini, A. (2017, June). What Drives Perceptions of Review Trustworthiness in Electronic Word-of-Mouth: An Experimental Study of TripAdvisor. In Atas da Conferência da Associação Portuguesa de Sistemas de Informação, 17 (17), 111-126

Chang \& Lu, (2015). Persuasive messages, popularity cohesion, and message diffusion in social media marketing. Journal of Business Research, 68(4), 777-782

Chang, L., Lee, Y., \& Huang, C. L. (2010). The influence of E-Word-Of-Mouth on the Consumer's Purchase Decision: a Case of Body Care Products. Journal of Global Business Management, 6(2), 1-7

Chao, R., \& Chen, H. (2016). The effect of product involvement on the relationship between electronic word-of-mouth and purchase intention: The cross-cultural comparison between Taiwan and Mainland China. Journal of Global Business Management, 12, 121-131. Retrieved from http://www.jgbm.org/page/13\%20Ren-Fang\%20Chao.pdf

Chen, Y., Chen, H., \& Xu, L. (2016, August). Social Media and eBusiness: Cultural Impacts on the Influence Process in Consumer Communities. In IOP Conference Series: Materials Science and Engineering, 142 (1). IOP Publishing

Chen, J., Teng, L., Yu, Y., \& Yu, X. (2016). The effect of online information sources on purchase intentions between consumers with high and low susceptibility to informational influence. Journal of Business Research, 69(2), 467-475

Cheong, H. J., \& Morrison, M. A. (2008). Consumers' reliance on product information and recommendations found in UGC. Journal of Interactive Advertising, 8(2), 38-49

Cheung, C. M., \& Lee, M. K. (2012). What drives consumers to spread electronic word of mouth in online consumer-opinion platforms. Decision support systems, 53(1), 218-225

Cheung, C. M., Xiao, B., \& Liu, I. L. (2012, January). The impact of observational learning and electronic word of mouth on consumer purchase decisions: The moderating role of consumer expertise and consumer involvement. In System Science (HICSS), 2012 45th Hawaii International Conference on (pp. 3228-3237). IEEE

Chiosa, A. R. (2014). WORD OF MOUTH ON SOCIAL MEDIA. SEA: Practical Application of Science, 2(4)

Chu, S. C. (2011). Viral advertising in social media: Participation in Facebook groups and responses among college-aged users. Journal of Interactive Advertising, 12(1), 30-43

Coulter, K. S., \& Roggeveen, A. (2012). "Like it or not" Consumer responses to word-ofmouth communication in on-line social networks. Management Research Review, 35(9), 878-899

Dellarocas, C. (2003). The digitization of word of mouth: Promise and challenges of online feedback mechanisms. Management science, 49(10), 1407-1424.

Diffley, S., Kearns, J., Bennett, W., \& Kawalek, P. (2011). Consumer behaviour in social networking sites: Implications for marketers. Irish Journal of Management, 30(2), 47 
Digital Marketing Definition | Investopedia. (2015, April 6). Retrieved December 18, 2015, from http://www.investopedia.com/terms/d/digital-marketing.asp

Edelman, D. C. (2010). Four ways to get more value from digital marketing. McKinsey Quarterly, 6

Eisingerich, A. B., Chun, H. H., Liu, Y., Jia, H. M., \& Bell, S. J. (2015). Why recommend a brand face-to-face but not on Facebook? How word-of-mouth on online social sites differs from traditional word-of-mouth

Evans, C., \& Erkan, I. (2014). The impacts of electronic word of mouth in social media on consumers purchase intentions

Flanagin, A. J., \& Metzger, M. J. (2007). The role of site features, user attributes, and information verification behaviors on the perceived credibility of web-based information. New Media \& Society, 9(2), 319-342

Gomez, L. M., \& Soto, I. (2011). Social Media as a strategic tool for Corporate Communication

Goodrich, K., \& De Mooij, M. (2014). How 'social'are social media? A cross-cultural comparison of online and offline purchase decision influences. Journal of Marketing Communications, 20(1-2), 103-116

Haigh, M. M. (2014). Comparing how organisations use websites and social media to maintain organisation-public relationships. Prism, 11(2)

Hennig-Thurau, T., Gwinner, K. P., Walsh, G., \& Gremler, D. D. (2004). Electronic word-ofmouth via consumer-opinion platforms: What motivates consumers to articulate themselves on the Internet? Journal of interactive marketing, 18(1), 38-52

Hoffman, E., \& Daugherty, T. (2013). Is a Picture Always Worth a Thousand Words? Attention to Structural Elements of eWOM for Consumer Brands within Social Media. NA-Advances in Consumer Research Volume 41

Hornik, J., Satchi, R. S., Cesareo, L., \& Pastore, A. (2015). Information dissemination via electronic word-of-mouth: Good news travels fast, bad news travels faster!. Computers in Human Behavior, 45, 273-280

http://studenttheses.cbs.dk/bitstream/handle/10417/1789/ann_christina_soerensen.pdf? sequence $=1$

$\mathrm{Hu}$, X. (2015). Assessing Source Credibility On Social Media - An Electronic Word-OfMouth Communication Perspective (Doctoral dissertation, Bowling Green State University)

Jalilvand, M. R., Esfahani, S. S., \& Samiei, N. (2011). Electronic word-of-mouth: Challenges and opportunities. Procedia Computer Science, 3, 42-46

Jansen, B. J., Zhang, M., Sobel, K., \& Chowdury, A. (2009). Twitter power: Tweets as electronic word of mouth. Journal of the American society for information science and technology, 60(11), 2169-2188

Kietzmann, J., \& Canhoto, A. (2013). Bittersweet! Understanding and managing electronic word of mouth. Journal of Public Affairs, 13(2), 146-159

Kim, E., Sung, Y., \& Kang, H. (2014). Brand followers' retweeting behavior on Twitter: How brand relationships influence brand electronic word-of-mouth. Computers in Human Behavior, 37, 18-25

Koo, D. M. (2016). Impact of tie strength and experience on the effectiveness of online service recommendations. Electronic Commerce Research and Applications, 15, $38-51$

Kwok, L., Kwok, L., Xie, K. L., \& Xie, K. L. (2016). Factors contributing to the helpfulness of online hotel reviews: Does manager response play a role? International Journal of Contemporary Hospitality Management, 28(10), 2156-2177 
Landsbergen, D. (2010, June). Government as part of the revolution: Using social media to achieve public goals. In Proceedings of the 10th European conference on egovernment (pp. 243-250)

Lee, M., \& Youn, S. (2009). Electronic word of mouth (eWOM) How eWOM platforms influence consumer product judgement. International Journal of Advertising, 28(3), 473-499

Lehmann, W. S. (2015). The Influence of Electronic Word-of-Mouth (eWOM) on College Search and Choice

Lin, C., Wu, Y. S., \& Chen, J. C. V. (2013). Electronic word-of-mouth: the moderating roles of product involvement and brand image. In Diversity, Technology, and Innovation for Operational Competitiveness: Proceedings of the 2013 International Conference on Technology Innovation and Industrial Management (pp. S3_29-47). ToKnowPress

Lobaugh, K., Simpson, J., \& Ohri, L. (2015). Navigating the new digital divide: Capitalizing on digital influence in retail. Deloitte, London, England

López, M., \& Sicilia, M. (2014). Determinants of E-WOM influence: the role of consumers' internet experience. Journal of theoretical and applied electronic commerce research, 9(1), 28-43

Mohammed Abubakar, A. (2016). Does eWOM influence destination trust and travel intention: a medical tourism perspective. Economic Research-Ekonomska Istraživanja, 29(1), 598-611

Moran, G., \& Muzellec, L. (2017). eWOM credibility on social networking sites: A framework. Journal of Marketing Communications, 23(2), 149-161

Nadeem, W., Andreini, D., Salo, J., \& Laukkanen, T. (2015). Engaging consumers online through websites and social media: A gender study of Italian Generation Y clothing consumers. International Journal of Information Management, 35(4), $432-442$

Nawaz, A., Vveinhardt, J., \& Ahmed, R. R. (2014). Impact of Word of Mouth on Consumer Buying Decision. European Journal of Business and Management, 6(31)

O’Reilly, K., MacMillan, A., Mumuni, A. G., \& Lancendorfer, K. M. (2016). Extending our understanding of eWOM impact: The role of source credibility and message relevance. Journal of Internet Commerce, 15(2), 77-96

O'Reilly, K., \& Marx, S. (2011). How young, technical consumers assess online WOM credibility. Qualitative Market Research: An International Journal, 14(4), 330-359

Park, D. H., Lee, J., \& Han, I. (2007). The effect of on-line consumer reviews on consumer purchasing intention: The moderating role of involvement. International Journal of Electronic Commerce, 11(4), 125-148

Park, S. (2017). Estimating the Effect of Online Consumer Reviews: An Application of Count Data Models. In Analytics in Smart Tourism Design (pp. 147-163). Springer International Publishing

Pedersen, S. T., Razmerita, L., \& Colleoni, E. (2014). Electronic Word-of-Mouth Communication and Consumer Behaviour-An Exploratory Study of Danish Social Media Communication Influence. LSP Journal-Language for special purposes, professional communication, knowledge management and cognition, 5(1)

Perrin, A. (2015). Social media usage. Pew Research Center.(n.d.). Retrieved January 21, 2017, from http://www.tezu.ernet.in/ utpal/course_mat/research_design.pdf

Peterson, R. A. (1994). A meta-analysis of Cronbach's coefficient alpha. Journal of consumer research, 21(2), 381-391

Romero, D. M., Galuba, W., Asur, S., \& Huberman, B. A. (2011, March). Influence and passivity in social media. In Proceedings of the 20th international conference companion on World wide web (pp. 113-114). ACM 
Schivinski, B., \& Dabrowski, D. (2016). The effect of social media communication on consumer perceptions of brands. Journal of Marketing Communications, 22(2), $189-214$

Schuckert, M., Liu, X., \& Law, R. (2016). Stars, votes, and badges: How online badges affect hotel reviewers. Journal of Travel \& Tourism Marketing, 33(4), 440-452

See-To, E. W., \& Ho, K. K. (2014). Value co-creation and purchase intention in social network sites: The role of electronic Word-of-Mouth and trust-A theoretical analysis. Computers in Human Behavior, 31, 182-189

Severi, E., Ling, K. C., \& Nasermoadeli, A. (2014). The impacts of electronic word of mouth on brand equity in the context of social media. International Journal of Business and Management, 9(8), 84

Sharif, M. A., Ahmad, W., \& Ahmad, A. (2016). „Electronic word of mouth: investigating the influence of electronic message source credibility, message appeal and brand equity on consumer purchase intention". City University Research Journal, 6(01), 151-165

Schmitt, N. (1996). Uses and abuses of coefficient alpha. Psychological assessment, 8(4), 350

Sørensen, A. C. (2010). A Process Model of Online Word of Mouth (Unpublished master's thesis). Copenhagen Business School. Retrieved from

Tewes, R. A. (2016). Two-way symmetrical communication and twitter in professional sports public relations (Doctoral dissertation, San Diego State University)

The Difference Between Word-of-Mouth and Viral Marketing. (n.d.). Retrieved December 24, 2016, from http://www.startup-marketing.com/the-difference-between-word-ofmouth-and-viral-marketing/

Themba, G., \& Mulala, M. (2013). Brand-related eWOM and its effects on purchase decisions: an empirical study of university of Botswana students. International journal of business and management, 8(8), 31

Toppi, A., Ulkuniemi, P., Saraniemi, S., \& Malaska, M. (2012). Corporate brand communication through social media in industrial markets. In IMP 2012 Conference

Vilpponen, A., Winter, S., \& Sundqvist, S. (2006). Electronic word-of-mouth in online environments: Exploring referral networks structure and adoption behavior. Journal of Interactive Advertising, 6(2), 8-77

Yogesh, F., \& Yesha, M. (2014). Effect of Social Media on Purchase Decision. Pacific Business Review International, 45-50

Yoo, K. H., \& Gretzel, U. (2008). What motivates consumers to write online travel reviews? Information Technology \& Tourism, 10(4), 283-295

You, Y., Vadakkepatt, G. G., \& Joshi, A. M. (2015). A meta-analysis of electronic word-ofmouth elasticity. Journal of Marketing, 79(2), 19-39 